\title{
Performativity and the Child Who May Not be a Child
}

\author{
John Stephens
}

Performativity, one of the most recent buzz words in literary studies, is a concept with complex origins, going back at least half a century. Some of the elements discussed under its rubric originate in the domain of theatre performance studies, while others are drawn from fields as diverse as anthropology, sociology, folklore, and cultural studies. An often free interchange between the terms performance and performativity is sustained by the simple fact that the verb to perform serves both nouns, so that while we can say that someone 'performs Shakespeare's Juliet' or 'performs femininity', it is easy to overlook that the verb is being used in quite different senses. It is perhaps not surprising, then, that one of the most prominent theorists of performativity over the past fifteen years, Judith Butler, declared early on in her use of the term that performativity "consists in a reiteration of norms which precede, constrain, and exceed the performer and in that sense cannot be taken as the fabrication of the performer's "will" or "choice" .... The reduction of performativity to performance would be a mistake' (Butler 1993, p.234).

If Butler's declaration is extended to apply to works of fiction, it might well be argued that performativity should normally be kept conceptually separate from performance, except when it is projected through performance in one of at least three forms. First, characters are represented in performance when depicted as engaged in overt roleplaying, as in embedded theatrical performance or in roles entailing disguise, such as cross-dressing. In such cases, the role is recognized or understood as already scripted before the performance and hence to a greater or lesser degree rehearsed prior to performance. Clearly, theatrical performance and disguise are of a different order from one another, but when represented in children's literature they share an overt awareness that there is a script to be followed. At its most effective, however, disguising can foreground the performative aspects of gender or class, for example, as Victoria Flanagan argues (2005, p.125). Second, characters are represented in performance when depicted as engaged in sporting events or other forms of structured competition. Here the rules that shape the outcome are overtly declared, but once more performance can body forth performativity, as in the case of the customdesigned children in Gloria Skurzynski's Virtual War, or when performance in a triathlon in Chris Crutcher's Iron Man figures masculine performativity. Third, characters are represented in performance when they are shown as self-consciously conforming to behaviour protocols other than those which readers come to recognize as their habitual mode of behaviour. Budge Wilson's well-known short story, 'My Cousin Clarette' (1990), offers an example - here Clarette's performance of the model, polite child when in the presence of adults is characterised by the story's narrator as a calculated act at odds with her habitual behaviour. We can read this as evidence of a fractured subjectivity, but what underpins it is, in Butler's terms, an act that has been going on before this particular actor arrives on the scene to perform it and that is perpetuated as a version of reality because individual performers take on subjectivity by actualizing and reproducing it. Once again, such performance has the potential to identify and interrogate behaviour grounded in performativity because it can highlight how performativity is a social construction. In everday life, subjects are apt to be unaware that they constantly reiterate the conventions and ideologies of the social world, are thereby shaped by those conventions and ideologies, and enact them with their bodies. Fiction writers may in turn reiterate those performatives in the process of character construction and in story conventions, but they are also privileged in the opportunity to reveal the constructedness of performatives through character and story, offering empirical models of a kind not available in Butler's theoretical descriptions.

Performativity in fiction, then, as distinct from performance, operates in a more metaphorical sense: readers recognize that a character is being depicted as 'performing an act', in a metaphorical sense, because we recognize a behavioural ritual which inheres in culture prior to the construction of this character. In other words, the character is constructed in accordance with, and so plays out, recognisable performatives. There is a significant political stake in this process in that, oriented toward the poststructural critique of the subject (which is one context we have for reading the Budge Wilson story, for example), it enables a redescription of norms and reinstates possibilities for agency and resistance. We have grown familiar with performativities which embody gender, class, or ethnicity, but I want to 
argue in this paper that one function of the relatively recent emergence in children's fiction of the posthuman highlights how throughout the history of children's literature humanity itself has been enacted as a performative. It can be seen through such texts that the characteristic narrative structures of character development, as organized in terms of, for example, the tripartite rite of passage structure of separation-liminality-reincorporation articulated by Victor Turner (1967; after Arnold Van Gennep, 1908), always embody performativity, a process already going on before a particular character is introduced into the scene.

This relationship between narrative form and performativity can be taken a step further, to the question of whether or not we can think of larger narrative form as performative. The observation that children's literature has remained wedded to narratives about individual development, pivoting on subjects acting upon the world, and striving to retain a sense of agency that allows for the possibility of resisting deterministic social and political structures, resonates with Katherine Hayles' argument in How We Became Posthuman that literary texts and scientific theories embody similar assumptions: 'the idea that stability is a desirable social goal, that human beings and human social organizations are self-organizing structures, and that form is more essential than matter' (1999, p.21). The form-matter relationship is particularly significant for young readers' apprehension of textual significance, since it is the variation of iterable form that instantiates significance: chronology, located actions, and personified agents may all be projected as performativity.

The possibilities of a posthuman agency can be articulated more clearly if Butler's reformulation of performativity in Bodies That Matter is reframed as an argument about being human. Non-human entities, such as robots or other mechanoids, are conventionally subjected to constraints which deny them agency, so it might therefore be expected that a non-human will take on the equivalent of humanity by overthrowing those constraints. It is not that simple, however, because, as Butler astutely argues, the agency denoted by performativity is only achieved within the regulatory norms which agential action might be expected to oppose. In other words, the subject is enabled, even produced, by such norms; it does not occupy a site of external opposition, but seeks agency within the reiterative practices of performativity by rearticulating those practices. As Butler is careful to argue, questions of agency cannot be resolved by asserting a constructivist stance and thereby asserting that because subjectivity is constructed, not essential, an individual is therefore free to construct subjectivity in whatever way she or he desires. On the contrary, subjectivity is constructed within a domain of constraints.

A particularly sophisticated example of how children's fiction can explore the processes whereby a subjectivity is formulated is Helen Fox's Eager (2003). The novel's eponymous principal character, a robot, asserts that he is free of the laws that constrain robots: 'I am not programmed to obey rules. I am programmed to learn and to think for myself. It is my choice how I behave' (p.103). On the contrary, though, the concept of performativity is grounded in the assumption that we are all 'programmed to obey rules', albeit not precisely in the sense that Eager is using here. Robotic 'intelligence' usually consists of programming, an assumption which in Eager is a kind of analogy for an essentialist theory of human being, linked to a model of passive learning. The robot Eager, in contrast, is not programmed with information, but, having been programmed with a child's vocabulary, is expected to make sense of the world by actively constructing knowledge along constructivist educational principles - that is, will learn meaningful behaviour by developing subjectivity within complex and ever unfolding relationships. A consequence of this program, which arguably evades the book's author, is that Eager and the humans with whom he interacts all perform a very conventional version of gender.

Eager's maker, Professor Ogden, is attributed with the belief that, 'if we give a robot the ability to feel emotion it will learn from its experiences, as a baby does. Because it has feelings and hopes of its own it will develop compassion for others, and learn the difference between right and wrong' (p.271). Such a specific version of the concept of intersubjectivity represents a very humanistic constructivism, an ethical ideal of human behaviour based on reasonableness and sympathy for others and their needs and on curbing the self-interests of individuals. The constraint on this process is, of course, that knowledge is always embedded in social 
and symbolic systems. How this constraint functions is apparent in the novel's opening:

\begin{abstract}
EGR3 stood in the small dark room and watched the sea. It tumbled and roared below him. The spray rose so high it threatened to touch him, but the wind carried it away before it could reach that far. The sky was black and lowering, and the sea a cauldron of grey. He could taste something familiar. What was it? Salt.
\end{abstract}

Both the scene evoked and the focalisation strategy by which it is evoked are very familiar. While the scene refers to prior knowledge readers might have, whether from life experience or other literary texts, it does not refer to a prior state of affairs but creates this character having this particular experience. At the same time, the experience is a cliché and the language reiterates the conventional language for describing this class of atmospheric situations: 'the sea ... tumbled and roared ... The spray rose ... high ... the wind carried [the spray] away ... The sky was black and lowering, and the sea a cauldron of grey.' We can think of this as a literary performative, whereby a particular set of collocated terms is deployed to embody an experience. On the other hand, it also alludes to the concept of performativity more generally, in that society does not merely furnish subjects with iterable concepts and ideologies, but it imposes linguistic categories with which to identify phenomena in the world and hence to organize the world rather than simply to represent what is. What Helen Fox is quite clearly doing here is enacting the relationship between an experiential process (in other words, a reiteration of norms) and the discursive conventions that frame interpretations. The relationship is enforced by the focalisation. The strategy of intense character focalisation has typified children's literature over the past forty years (coinciding, incidentally, with the era of postmodernism). In this passage we have an entity identified as EGR3 whose activity is marked by substantial focalization. First, we have the perceptual terms watched and could taste, framing the observational activity. Readers will understand that everything depicted between these terms is being seen and felt by EGR3. Second, following the reference to taste, the text segment closes by slipping into Free Indirect Thought, in the form of a question and answer. EGR3 is obviously an embodied entity: he is gendered; he stands; he experiences threat; he tastes; he thinks. What, then, is the nature of the cultural meanings that emerge between the utterance that asserts the presence ofEGR3's body and the conventions of embodiment evident in the focalization strategy and the linguistic organization of perception? EGR3 is performing the act of looking at the sea and in doing so illustrates how performativity is grounded in the materiality of reiterated performance.

Readers might be wondering about someone named EGR3, but will nevertheless have little difficulty in accepting this as an 'authentic' experience: it indicates an engaged and emotional response to landscape, which in turn suggests a reflective interiority, and the implicit appeal to memory points to a will to comprehend experience as integrated and consistent. The text soon discloses, however, that EGR3 has never left this room, but is experiencing the world by means of a virtual reality program. What constitutes experience and knowledge is thus already being declared as one of the novel's themes. EGR3 responds interactively: 'And all the time his brain was asking, and comparing, and cataloguing, and storing away the experiences'(p.2). Within this short list of constructivist processes is a shift from literal mental activity (asking, comparing) to a metaphorical use of material processes (cataloguing, and storing away). A reader might scarcely notice the shift, since these are such everyday metaphors, but the shift is effectively preparing the ground for the imminent disclosure that EGR3 is a robot undergoing a rather special kind of programming, the outcome of which is to shift robot cognition from essentialism to constructivism, and to break the nexus between embodiment and performativity.

In teasing out the question of whether an artificial intelligence can be deemed to be 'alive', Eager raises the key issue of what it is to be human. Is the robot a lesser sentient being than the clone of Nancy Farmer's House of the Scorpion (2002), or the genetically engineered characters of Gloria Skurzynski's Virtual War (1997)? For Gavin Bell, the young boy in the family Eager is assigned to, Eager is not alive because he is not an organism and cannot reproduce organically. On the other hand, Eager has many human attributes: he can 'see and think and talk 
and move' (p.214); he feels he is alive (p.215); he is aware that he exists and can reflect on his actions - that is, he can choose how to behave (p.226). In short, he performs humanity.

Because performativity is embedded in social practice and historical contingency, it can be made visible, described, and redescribed. The concept has entered the critical discourse pertaining to children's literature at an opportune time. Throughout the last third of the twentieth century - what we are now coming to think of as the 'theory era' - the ideology underpinning children's literature remained predominantly humanistic. In the closing years of the century, however, some of the principal concerns of that era somewhat belatedly entered children's literature. Subjectivity began to be perceived as fragmented, or constructed from moment to moment within relations of difference; the question of how biological bodies become culturally expressive was addressed as bodies were perceived as gendered not by biological actualities but by social and historical performatives; just as selves no longer have a necessary fixity, everyday activities are no longer understood in relation to clear rules, or abstract moral values, or other metanarratives, but have become contingent. One of the possibilities facing the world at the beginning of the $21^{\text {st }}$ century is the prospect that we are entering a post-human era, and thus a new range of concepts has began increasingly to enter children's literature - the cyborg, virtual reality, technoculture, cloning, genetic engineering. In short, children's literature has begun responding to the idea of the posthuman and accessing the two areas most commonly linked to the posthuman: biological interventions into the human body - cloning, genetic manipulation, 'test-tube' creation of human life - and cybernetic interventions that either modify the human body or fashion artificial life in its evolutionary image. ${ }^{1}$

The prospect of a posthuman future suggests that bodies might be thought about in new and different ways. Hayles (1997, p.242) suggests the following: the patterning of information flows may be more significant than physical existence (a possible way of reading EGR3's processing of his experiences); consciousness, regarded as the seat of human identity in the Western tradition, might be recognized as merely a late development in human history; extending or replacing the body with other prostheses becomes a continuation of a process that began before we were born; human being can be seamlessly articulated with intelligent machines.

So far, with cautious exceptions such as Gloria Skurzynski's Virtual War, fiction for young audiences has shown little inclination to embrace such a perspective, and futurist texts seek rather to determine what value might oppose a metanarrative grounded in the end of human subjectivity. That value is usually some sense of being human. Reaffirmation of that value is then expressed through redescriptions of performativity, especially in order to address the problematic role of individual agency within late twentieth century social and cultural theory. Because children's literature has remained wedded to narratives about individual development, pivoting on subjects acting upon the world, it has mostly striven to retain a sense of agency that allows for the possibility of resisting deterministic social and political structures. Hence the questions it (implicitly) asks by means of its thematically nuanced narratives coincide quite closely with Judith Butler's performative model for thinking about social processes:

- What is identity and how is it produced?

- How do social norms function?

- How far is agency possible? Is it possible to be a responsible subject who chooses her/his acts?

- What are the relationships between individuals and social change? How should we conceive of the relation between the conventions that constitute and enable social life and individual acts?

- How do we engage with the ways in which language shapes and organizes our experiences of the world?

The 'children' produced under the conditions of an imagined posthuman future have the potential to challenge our concepts of humanity and posthumanity: if such a child performs childhood, and that performativity embodies subjective agency, can it be confidently asserted that she/he/it is not a child? Conversely, if a human child 
cannot be said to perform childhood in the same way, why should we not decide that she or he is less than human? For example, when Fleur Bell walks through the city streets unaccompanied, on the way to visit a friend living nearby, she has an almost euphoric illusion of agency: 'It was intoxicating to walk on her own, to have a sense that she might choose to do whatever she wanted, even if all she did was visit Marcia' (Fox 2003, p. 44), but of course this feeling marks her customary lack of agency. Similarly, in a simultaneously occurring scene, her brother Gavin is reminded of the limited agency of childhood. When Gavin here meets EGR3 for the first time, and is confronted with the suggestion that a robot might develop a capacity to feel emotions that can't be taught in computer simulations - 'Love, loyalty, kindness, joy, compassion, courage, fear, envy, anger, loss' (p. 60) — his reaction is to cry out, 'But what exactly can it do?'. His crude separation of doing and feeling is countered by the question, 'Tell me first, young man ... what can you do?' (p. 61), a question that implies that he is not yet fully human. The attempts to define a future version of humanity we find in such children's literature accord better with an alternative view that the posthuman does not necessitate either an evolution or devolution of the human. Rather it means that difference and identity are being redistributed. Ideas of humanity - that is, 'the human' - naturalise and hierarchise difference within the human (whether according to race, class, gender) and make absolute distinction between the human and nonhuman. Ideas of the posthuman question what we consider to be 'natural', and create possibilities for the emergence of new relationships between human and machine, biology and technology.

A number of symptomatic texts in addition to Fox's Eager represent this emerging area of children's literature. Like Eager; Chloë Rayban's Virtual Sexual Reality (1994) primarily involves cybernetic intervention. Texts falling within this category include characters who are either machines, part human and part machine, or have nonhuman components. Biological interventions are dealt with in Gloria Skurzynski, Virtual War (1997), and Nancy Farmer, The House of the Scorpion (2002), two novels which include characters who owe their existence to genetic engineering.
Children's fictions engaging with notions of the post-human are characterized by the following topics:

- Subjectivity and agency

$>$ Individual identity is fragmented, tenuous;

> Being human is performative (humanity is enacted rather than defined within particular narratives);

> The 'hybrid subjectivity' of the posthuman/cyborg/robot constantly moves between nature and culture, organic and synthetic, individual and collective.

- Representation of the body (virtual body): relationship between body and space; how boundaries and oppositions are constructed.

- Society/nationhood/city (roles of technology/ science).

- Paranoia and conspiracy within posthuman social structures (that is, the political hegemony of corporations within utopic/dystopic narratives )

Virtual Sexual Reality neatly exemplifies the continuation of narratives about individual development into posthuman narrative, and can be mapped closely onto Turner's account of a rite of passage: separation, liminality, reincorporation. Separated from her everyday female life by an encounter with a virtual reality machine that reconstitutes her as a virtual male, Justine for most of the novel inhabits liminal space as 'Jake'. This is literally a liminal geographical space, as she has no home, no clothes, no money, no recognized place at school. In The Forest of Symbols, Turner emphasizes that liminality is a transformational period in which the subject acquires arcane knowledge capable of changing her or his inmost nature. Anthropologically, liminality positions initiates between the person they no longer are and the person they are yet to become. Rayban employs Justine's liminal gender to render her aware of gender performatives. According to Turner's schema, when the subject is reincorporated into the social order she will assume a new role and status. Butler argues that performatives are neither natural nor essential, but historically constructed and endure because they are continually cited or enacted, and hence they can be challenged and changed through alternative performative 
acts $(1988$, p.520). If this assumption is embodied as a narrative structure by combining it with Turner's idea that a subject in a liminal state is able to introduce new elements into the 'socially inherited deposit of ritual customs' (1982, p.31-32), we can see the potential in exposing performatives. This novel doesn't achieve a sophisticated insight, but does incorporate some extended redescriptions of gender performatives, using posthuman experience to comment on the performativity of being human.

Eager, while written for a younger audience, offers a more sophisticated attempt to explore the extent to which performativity constitutes human subjectivity, as the shape of a world to come is narrated in the context of key metanarratives which seek to scrutinize what it is to be human through representations of mechanoid experiences and perceptions (Descartes' cogito always lurks on the edges of perception: 'I perceive, therefore I am; I feel, therefore I am'). Eager likewise invokes the story of Frankenstein's 'monster' (p.270), in its contrast between new types of robots which have been freed from Asimov's 'laws of robotics' which stipulate that robots cannot harm or deceive people: ${ }^{2}$ on the one hand, the BDC4 series, programmed with actual human memories; and on the other hand, the prototype Eager, who is programmed to learn by understanding and to feel emotion and exemplifies that artificial life may still be life as we know it. A brief glance at a scene in which Eager encounters the BDC4 robots illustrates Fox's strategy in this novel:

He could scarcely believe that he would soon be
in the presence of these magnificent robots. As he
drew near, the door of the building slid open and
a dozen BDC4s stepped out, two abreast. Even in
the faint sunlight their metals were dazzling. They
appeared so purposeful and strong that Eager
shrankback against the wall. This was not what he
had intended to do, but by the time he summoned
his courage and shouted 'Wait!' 'they were striding
across the grass.

Eager watched them, fascinated. They kept together, walking with identical paces to the same rhythm. Step, step, step, step, step, step. When they reached the path they turned sharply to the right and went down the hill. They had not noticed him or, if they had, they showed no sign of it.
Eager ran across the field, his toes pulling at the grass, not stopping until he was halfway up the slope again. Above him rose a huge fluffy ball of pinkblossom. The tree was the loveliest thing he had seen all day. He gazed up at it, feeling something of the awe that he had for the robots. Unlike the $B D C 4 s$, the tree seemed to be accepting of him. If only it could talk and move! He remembered the conversation with Fleur in the garden, and realized that he too was lonely.

(Fox 2003, pp. 134-5)

Eager focalises the scene, so is attributed with narrative consciousness and awareness. He feels emotions and desires: 'excitement'; desire for friends; loneliness. He has awareness of the otherness of the world: the dampness of the grass under his 'feet'; the beauty of the flowering tree. The narrative presents him as if he were a human being, as the distinction between the human and non-human begins to dissolve, and what we imagine as 'natural' feelings are attributed to the machine.

A question posed by such an episode is whether consciousness is evoked as the seat of human identity or whether it can be an attribute of an artificial intelligence. The ultimate contrast between Eager and the BDC4s he admires so much is that he has been programmed to learn responsively, and they have been programmed with actual human memories but no selfconsciousness, and are thereby driven insane by a conflict within their cyborged being. Is Eager incipiently human, or does his programming construct a monologue of perceptions which creates the illusion of a coherent and unified self?

The two novels referred to above whose principal (and focalising) characters have been genetically engineered address this issue in a different way. In general, at least up to the present time, children's fiction seems more comfortable with the creation of artificial intelligence than with the possibility of genetically modified human beings. Where the latter appears in fiction it is normally within a representation of a dystopian world. This conjunction is very evident in Virtual War and The House of the Scorpion.

'By the year 2080, plague, disease, terrorism, and nuclear war had confined Earth's two million survivors to a few 
domed cities ...': so begins Gloria Skurzynski's The Clones (2002), sequel to Virtual War (1997). Five years after the publication of the first volume, the conventional causes of the near eradication of humanity in post-disaster fiction are here augmented by the American response to September 11, 2001, and Skurzynski has apparently been prompted to rewrite the list that appeared in Virtual War (pp.15-16): the ebola epidemic; nuclear war; the next two Chernobyl accidents; AIDS; dengue fever; hanta virus. The careless elevation of 'terrorism' to the status of global disaster, together with the unusual retention of nuclear war and continued omission of ecological disaster (which had replaced nuclear war in most post-disasterfictions published since the end of the Cold War), make this the first postdisaster fiction to offer implicit endorsement of US post9/11 global policies such as the 'War against Terrorism' and the refusal to recognise the ecological problem of global warming. As with most post-disaster fictions since 1990, Virtual War envisages a posthuman world governed by a faceless oligarchy - that is, the dystopian penalty for failing to resist social and political trends in motion at the end of the twentieth century. Here the world has been reduced to three civilisations (a reduction of the seven or eight post Cold War civilisations adduced by Samuel $\mathrm{P}$ Huntington in his 'Clash of Civilisations' theory). ${ }^{3}$ After the Central Pacific Isles of Hiva (formerly the Marquesas) are declared decontaminated and safe for occupation, the three world powers agree to fight a scientifically controlled, eight-hour war for control of the islands, using only virtual soldiers. Corgan, the character from whose point of view the story is narrated, is a 14-year-old genetically engineered test-tube baby, produced with the sole purpose of fighting this war on behalf of the Western Hemisphere. His two teammates, a cryptographer and strategist, are likewise laboratory-bred products of genetic engineering. Their humanity, nevertheless, is assumed as something given: they are 'superior', even 'supreme' (p. 33), but still human. The story pivots on a contest, and hence on performance, but in order to achieve performance at the level required, the characters are raised and kept in a virtual domain shaped and conditioned by traditional performatives. The first time Corgan sees Sharla in reality (as opposed to her virtual image) his perception is coded in terms of a traditional masculinity:
He saw that her hair was shorter than on the Go-ball court, yet it looked more golden. And her mouth! For a long moment he let the light shine on it. No virtual image could ever do justice to those full, moist lips.

(Skurzynski 1997, p.39)

As we saw with Fox's Eager, focalisation, representation of character thought processes, and conventionality of language and referent are combined, here to constitute a particular performative - specifically, a version of the male gaze. The egregious cliché 'full, moist lips', in particular, indicates the extent to which the text endemically invokes conventional feminine attributes and masculine responses to them. Similarly, the virtual parent-figure who is Corgan's trainer and care-giver transforms between gender-stereotyped stern paternal roles and comforting maternal roles. It seems that to avoid the possibility that the genetically-engineered super humans of the future might seem other than human, they are gendered in a retrograde fashion assumed to be a permanent and uninterrogated cultural structure. This is solidly confirmed when Corgan's reward for successfully leading his virtual soldiers through a bloody war is to lead a 'natural' life as a farmer.

In contrast, the principal character of Farmer's The House of the Scorpion is a clone, and for most of the novel is repeatedly told that he is not human; that 'Clones aren't people' (p. 26). The novel opens with a description of his production from frozen cells, presenting this process not as the creation of a human being, although human attributes are invoked, but as a production line. The purpose of Matt's existence, as he eventually discovers, is to be a reservoir of body parts, especially his heart, for El Patron, ruler of Opium, a country that lies between the United States and Aztlán, formerly Mexico. Eventually permitted to be educated, but kept on the periphery of El Patron's household, he performs humanity, until he finally learns that he has always been human and, El Patron having died, he is no longer the simulacrum but the real thing. Like each of the other books referred to, The House of the Scorpion focuses on the questions of the social implications of technological advances, what it means to be human, and what constitutes human being and becoming. 
At present, the central question posed by the emerging genres of posthuman narratives is this: what potential does the concept of the posthuman offer children's literature to make visible the performatives which organize sociality and subjectivity, to interrogate those performatives, and to explore possible new ways of being? Can it throw any new light on, for example, how children develop gendered behaviours? Virtual War distributes its skills amongst its three genetically engineered characters along lines which are implicitly gendered: of the older two, Corgan is more physically skilled and active, while Sharla is more skilled in particular cognitive tasks. She is also more devious, and the novel invokes a familiar contrast between the open, physical-task oriented male and the subtle, manipulative female. Thus while the landscape of the future world is imagined to be quite different, human subjects are still shaped by the same performatives. Such an outcome points toward something of a paradox in this fiction. Whether produced by cybernetic or genetic engineering, children are depicted as shaped by the social world. Their actions, reactions and interactions may impact upon particular events, but have little effect in shaping the social world. Eager and Gavin seem ultimately to share a common humanity, but they also share a common childhood state of waiting to become: waiting to become adult, waiting to become fully human.

If we ask how the posthuman characters experience the movement from liminality to social reincorporation, we would conclude that their experiences reinforce performatives by assimilating the cybernetic, the genetically engineered and the non-human to the human. This happens in a simple way in Rayban's Virtual Sexuality Reality when Justine's virtual other is erased. Ultimately, the cybernetic possibility has proved to be a useful plot device, but is unable to tell readers more about gender than can be told by a female-to-male cross-dressing narrative closing with a comparable reincorporation. Virtual War distributes rewards to its three principal characters in the form of careers or life-tasks they wish to pursue, and while each involves research in genetic engineering, each is other-regarding or altruistic in focus. The close returns the characters to a familiar human world, and this is again underpinned throughout the final two chapters by threading the interactions between Corgan and Sharla with conventional feminine attributes and masculine responses to them. The novel fails, I think, to distinguish conceptually between the innate and the performative. The close of The House of the Scorpion affirms that Matt has always been human and installs him as leader of the country of Opium, with the task of winding the world back to a more humane state. Out of the ruins of El Patron's private dystopia will emerge not a new world, but the old world.

What I miss in these books is a use of the posthuman to suggest other forms of awareness, or different subjectivities. Eager comes closest to achieving such an insight because it is able to use the performativity inherent in the separationliminality-reincorporation structure to affirm that the robot Eager constitutes a mechanoid humanity whose consciousness and self-awareness transcend mechanical component parts, and survive repairs and replacement of parts. Thematically, nevertheless, the novel is as much about the need 'to remember what it means to be human' (Fox 2003, p. 298) as about the possibilities of artificial intelligence. And so far, I suggest, that is the broad theme of posthuman narratives in children's literature.

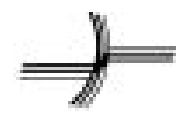

\section{NOTES}

1. My discussion draws upon a presentation on the posthuman in a panel discussion with Victoria Flanagan and Robyn McCallum at the 2004 ACLAR conference.

2. Isaac Asimov's 'Three Laws of Robotics' are alluded to by Eager when the family's old robot asks him about the first law of robot behaviour: 'A robot must never harm, or allow harm to be done to, a human being. A robot must never do anything that might endanger a human being. A robot must not harm itself or another robot, unless the other robot is endangering a human being' (p. 103). The second and third laws are: 2. A robot must obey orders given it by human beings except where such orders would conflict with the First Law. 3. A robot must protect its own existence as long as such 
protection does not conflict with the First or Second Law.

3. First advanced in 1993 in Samuel P. Huntington, 'The Clash ofCivilizations?', Foreign Affairs, 72/3. Available at: http://www.georgetown.edu/faculty/irvinem/ CCT510/Sources/Huntington-ClashofCivilizations1993.html

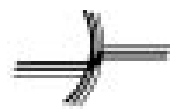

\section{REFERENCES}

Butler, Judith (1993) Bodies That Matter. New York and London, Routledge.

(1988) 'Performative Acts and Gender Constitution: An Essay in Phenomenology and Feminist Theory', Theatre Journal 49.4: 519-531.

Culler, Jonathan (2000) 'Philosophy and Literature: The Fortunes of the Performative', Poetics Today 21.3: 503-519

Farmer, Nancy (2002) The House of the Scorpion. New York, Atheneum Books.

Flanagan, Victoria (2005) 'Emerging Identities: Cross-Dressing and Sexuality in Adolescent Fiction', in Emer O'Sullivan, Kimberley Reynolds, and Rolf Romøren (eds), Children's Literature Global and Local: Social and Aesthetic Pespectives. Oslo, Novus Forlag, 125-136.

Fox, Helen (2003) Eager. London, Hodder.

Hayles, N. Katherine (1997) 'The Posthuman Body: Inscription and Incorporation in Galatea 2.2 and Snow Crash', Configurations 5. 2: $241-266$

Hayles, N. Katherine (1999) How We Became Posthuman. Chicago and London, University of Chicago Press, 1999.
Rayban, Chloë (1996 [1994]) Virtual Sexual Reality. London, Red Fox.

Skurzynski, Gloria ([1997] 1999) Virtual War. New York, Simon Pulse.

(2002) The Clones. New York, Atheneum Books.

Turner, Victor (1967) The Forest of Symbols: Aspects of Ndembu Ritual. Ithaca, Cornell UP.

(1982) From Ritual to Theatre: The Human Seriousness of Play. New York, PAJ Publications.

Van Gennep, Arnold ([1909] 1960) The Rites of Passage. London, Routledge \& Kegan Paul.

Wilson, Budge (1990) My Cousin Clarette and Other Stories. St Lucia, University of Queensland Press.

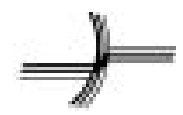

\section{BIOGRAPHICAL NOTE}

John Stephens is Professor in English at Macquarie University, Sydney, Australia, where he teaches and supervises postgraduate research in children's literature, as well as in other literatures. He wrote Language and Ideology in Children's Fiction; Retelling Stories, Framing Culture (co-written with Robyn McCallum); two books about discourse analysis; and around sixty articles about children's (and other) literature. More recently, he has edited Ways of Being Male: Representing Masculinities in Children's Literature and Film. His primary research focus is on the relationships between texts produced for children and young adults (especially literature and film) and cultural formations and practices. 